\title{
Cinememory: Sexualized Trauma and Coming of Age in Holocaust-Related Israeli Films
}

\author{
Sandra Meiri \\ The Open University of Israel, Raanana, Israel
}

\begin{abstract}
Since 1978 Israeli Holocaust-related narrative films have associated the violence experienced during the Holocaust, including sexual violence, with the violence permeating Israeli society. In keeping with Marianne Hirsch's notion of "postmemory", this paper argues that cinema, as a visual form of artistic mediation, has an especially strong impact on the spectator, because it triggers affective, tactile, and bodily responses. Hence, the efficacy of generating an ethics of remembrance of sexually-related violence, based on cinematic aesthetics, which the author terms here "cinememory". The paper focuses on a sub-genre of Holocaust-related films: coming-of-age films, which explore in different ways the lasting implications of growing-up in the shadow of sexualized trauma; the unconscious transmission of memories and tactile experiences, related to the ubiquity of sexual violence during the Holocaust.
\end{abstract}

Keywords: coming-of-age, sexualized violence, transgenerational trauma, cinememory, ethics of remembrance

\section{Women's Trauma, Men's Cinema}

The earliest approach to grappling with sexual violence in the Holocaust on a large scale was that of the controversial literature by Auschwitz survivor, Yechiel Feiner (Yechiel Denur). His books, House of Dolls (1955 [1953]) and Atrocity (1963 [1958]), published under the pen name "Ka-tzetnik 135633", depict sexual slavery and abuse in concentration camps-the first of a young woman (the narrator's sister) and the second of a young boy-the narrator's brother. The two volumes are part of a long chronicle of the horrors of the camps, which Ka-tzetnik began with Sunrise over Hell (1977), first published in 1946, relating the story of a Polish-Jewish family in Auschwitz. The second attempt to address sexual violence in the Holocaust was that of the even more controversial literature of the Stalags, a phenomenon that emerged at the commencement of Adolf Eichmann's trial, in April 1961. The period of the trial was the first time that Israel had been publicly confronted with the incomprehensible memories of Auschwitz, unvoiced until then. A few months later the Stalags flooded the kiosk stands. These were pocket-sized books depicting lusty female SS (Schutzstaffel, Protection Squadron) officers sexually abusing camp prisoners-mostly American and other Allied POW (prisoners of war). During the 1960s, sales of this pornographic literature broke all records in Israel. The Stalags were written in Hebrew, by Israeli writers, in the style of genuine memoirs, masquerading as translations from English. In 1963, the court found the publishers of these works guilty of disseminating pornography. Their popularity, however, was in effect already declining because the market had reached a point of saturation.

\footnotetext{
Sandra Meiri, lecturer, Department of Literature, Language and the Arts, The Open University of Israel.

${ }^{1}$ Feiner took this acronym from the German abbreviation KZ (Konzentrationslager, concentration camp) for concentration camp inmates. On its significance, see Abramovich (2007, pp. 21, 25).
} 
Serious studies on both Ka-tzetnik's works (Szeintuch, 1999, 2003, 2009; Abramovich, 2007; Sivan, 2010) and the Stalags (Pinchevski \& Brand, 2007) are scant. We learn from Ka-tzetnik's two books that sexual exploitation was an integral part of the Holocaust, irrespective of gender. Nonetheless, the thinking on gendering the Holocaust has inevitably turned the spotlight (and rightly so) on what is typical to women's endurance during war and genocide - the assault on motherhood and various forms of sexual crimes. Following Joan Miriam Ringelheim's pioneering articles $(1984,1985)$, a vast number of books and articles (their data accumulated over the years from diaries, memoirs, letters, and testimonies), have explored gender-determined forms of suffering, behavior, and victimization (e.g., Allen, 1997; Baer \& Goldenberg, 2003; Baumel, 1998, 2000; Bergen, 2013; Dror \& Linn, 2010; Goldenberg, 1996; Heinemann, 1986; Horowitz, 2000; Jacobs, 2010; Kremer, 1999; Linden, 1993; Mushaben, 2004; Ofer \& Weitzman, 1998; Pine, 2008; Ringelheim, 1984, 1985; Rittner \& Roth, 1993; Saidel, 2006; Schoenfeld, 2001; Smith, 1994; Tec, 2003; Waxman, 2003). Almost all the studies on gender and the Holocaust affirm that women qua women experienced the horrors of the camps as an assault on sexuality (e.g., Chatwood, 2010; Doerr, 2000; Flaschka, 2010; Goldenberg, 2013; Halbmayr, 2010; Levenkron, 2010; Myers, 2007, p. 155; Pine, 2008, pp. 124, 128, 135; Podolsky, 2010; Ringelheim, 1984, 1985; Sinnreich, 2010; Sommer, 2010; Waxman, 2003, p. 666; Waxman, 2010)and on motherhood (Amesberger, 2010; Ben-Sefer, 2010; Goldenberg, 1996, p. 670; Horowitz, 2000, pp. 163, 170, 180 (n. 35); Mushaben, 2004, pp. 156, 166; Patterson, 2013; Pine, 2008, pp. 124, 133-134; Waxman, 2003, pp. 669, 672, 674). Men's memoirs, and other autobiographical-based literature on the time spent in the camps, focus primarily on crimes against humanity, and some even express their objection to the gendering of extreme suffering. ${ }^{2}$ The few gender studies centering on men's unique experience during the Holocaust describe the loss of paternal authority, and thus of self-value (e.g., Myers, 2007).

Israeli Holocaust-related cinema has always validated the ubiquity of sexual violence in relation to women, thus breaking the silence in the social sphere. Early films, like My Father's House (1947), The Great Promise (1947), The Faithful City (1952), and The Sun Rises on the Horizon (1960), paved the way to later forms of cinematic representation, visually and aesthetically evincing film's ethical role in legitimizing the disclosure of sexual violence as a crime committed against helpless victims. Such are Wooden Gun (1978), Tel Aviv-Berlin (1987), and Newland (1994). Films, like Burning Mooki (2008), Intimate Grammar (2010), and Once I Was (2010), suggest that society's protracted silence or contempt in regard to women's trauma has enhanced the transmission of its post-traumatic symptoms and that its violence has penetrated Israeli society on many levels (such as the military). This notion, vicariously laid out in Wooden Gun, has been developed in the Holocaust-related films made in the 2000s within a coming-of-age paradigm, focusing on the second generation's experience.

Creating a film whose female protagonist is a survivor of sexual abuse might still be considered by many as a desecration of Holocaust memory. Such cinematic representations are scant worldwide, and in Israeli cinema, they have remained marginal. The fear of (re)opening wounds entailing a deep sense of helplessness, guilt, and shame is particularly germane in regard to representation of the sexual exploitation of men. To date only one documentary has been made in Israel on this subject: Josef and Maria (2007) tells the story of a 70-year-old Holocaust survivor, Josef, who falls in love with a German-Christian woman, Maria, and finally

\footnotetext{
${ }^{2}$ For a critical discussion, see Horowitz (2000, p. 180), Pine (2008, p. 121), and Ringelheim (1984).
} 
manages to make a life for himself. For decades, he had been tormented by the memory of being repeatedly raped as a child in a forced labor camp:

The first time it happened, we came from a long working day. It was in a forced labor camp. All I wanted to do is sleep, but I was taken somewhere, and told that something special was going to happen to me. Stripped of the few rags covering my body, I was raped. I screamed with pain... afterwards others came, it happened every night, I was repeatedly raped... This is how it went on, for a year, during the day you worked and during the night you were raped.

Until he met Maria, Josef's life had been that of a recluse. Barely able to make ends meet, with very low self-esteem (affirmed by his neighbor's voice-over-"he was a passing shadow, almost non-existent, and even tried committing suicide a few times" (2007)), he was convinced that his life was worth nothing. For a while, he was homeless and spent his nights in a park frequented by gays. Josef's story leaves no doubt as to the intensity of feelings of shame and worthlessness in regard to sexual violence. However, it also suggests that being finally able to speak about such experiences may pave the way to a new life. Back on the park bench, where he had used to spend his nights, Josef still chokes back his tears when bringing his past to light, but he is finally able to see how, as an adult, he had acted-out his sexual experiences as a child. He feels sickened when he realizes how being homeless and spending his nights in this particular park had been a form of reenacting his past experience, and we cannot help wondering what role the camera has played in this new experience.

Israeli narrative cinema's fear of representing men as victims of sexual violence is primarily linked to this cinema being male-dominated. ${ }^{3}$ Referring to Tel Aviv-Berlin, Gertz (2004) writes: "The film does not deconstruct the old opposition of the early cinema... still adhering to the role designated for women in that cinema-as an empty sign supporting man's identity; only this time-it is the survivor's identity" (p. 48). Although, as the author aims to show, the portrayal of women survivors in Israeli cinema is by no means an "empty sign", the author nevertheless agrees with Gertz's assessment. This adherence to portraying only women's sexualized trauma reflects, however, not only a fear of effeminacy, but also an inner dialog with the early Holocaust-related cinema.

The early films (1947-1960) were "resurrection narratives" (Avisar, 2011, p. 153). The aim of films like The Great Promise, My Father's House, and The Faithful City, was to demonstrate how physical labor, exercise, pioneering settlement of the land, and military training might erase the shameful memory of the passive, Diasporic, effeminate Jew. Their protagonists were orphaned children, aided and mentored by high-spirited settlers (of all ages), which ensured the credibility of the Zionist master-narrative (Zimmerman, 2002, pp. 59-60). With the exception of The Cellar (1963), made in the wake of the Eichmann trial, and later of Tel Aviv-Berlin, whose protagonists are adult survivors haunted by their horrific experiences, all the Holocaust-related films' protagonists, beginning with Wooden Gun (1978), are either children or teenagers. Films like Newland, Burning Mooki, Intimate Grammar and Once I Was, evince women's susceptibility to sexual crimes during the Holocaust, and simultaneously render the old Zionist narrative paradigm, which supported the ideal of a new, masculine, Jew, null and void.

These films uphold the notion that because sexually-related forms of violence were privately repressed (and understandably so), and collectively suppressed, as part of the general agenda of creating the "new Jew", they were reenacted in various forms by survivors and unconsciously transmitted to the second generation. Wooden Gun explicitly shows how children reenact this transmission of violence suffered by their parents in

${ }^{3}$ For an elaboration on Israeli cinema and masculinity, see Yosef (2004). 
the Holocaust, while imitating and reiterating the violent behavior of the ideal new (and virile) Jew. Made at the turn of the decade (1978), marked by the apprehension of a radical change in Israeli politics (after the 1977 political upheaval ${ }^{4}$ ), the film expresses a deep concern with the inculcation of the ideal of the heterosexual virile fighter stereotype into Israeli society and culture. It thus subverts the early films' narrative paradigm, in which the young protagonists are Holocaust survivors who join the young settlers and fighters. In Wooden Gun, in contrast, the young protagonist is an Israeli-born, who, at the end of the film, turns his back on his violent friends, embracing the pariah-a female Holocaust survivor. ${ }^{5}$

Written, or written and directed, by male filmmakers who belong to the generation that matured in the shadow of trauma, ${ }^{6}$ films made during the 2000s developed the narrative pattern established in Wooden Gun (and Hide and Seek) as the sub-genre of "coming-of-age films", representing what Marianne Hirsch calls "the generation of postmemory": "Postmemory describes the relationship of the second generation to powerful, often traumatic, experiences that preceded their births but that were nevertheless transmitted to them so deeply as to seem to constitute memories in their own right" (Hirsch, 2008, p. 103). The crux of postmemory is that it is aesthetically mediated. Hirsch, who focuses on photography, argues that visual forms of artistic mediation have a much stronger impact on the spectator, because they trigger affective, tactile, bodily responses (Hirsch, 2008, p. 117). Hence, the efficacy of generating an ethics based on visual aesthetics. This is undoubtedly true of cinema, which has the capacity to invoke even our sense of smell. ${ }^{7}$ The coming-of-age Holocaust-related films suggest, in different ways, that the unconscious transmission of remembrance and tactile experiences of sexualized violence was an integral part of growing up in post-Holocaust Israel. The author begins her discussion with the documentary film Stalags (2007), for two reasons: First, it deals with the earliest approaches to grappling with sexual violence in the Holocaust-Ka-tzetnik's literature, and the Stalags-with the latter generated directly from the surfacing of private and collective traumas during the Eichmann trial; and second, it depicts the concern of the film-makers with sexual violence as a result of having lived a violent childhood, in the shadow of trauma, with this theme being a central one in the coming-of-age films.

\section{In the Shadow of Trauma}

Stalags openly addresses the question of the ubiquity of sexual violence in the Holocaust. It explores the links between the initial approaches to contending with the Holocaust in Israel: Ka-tzetnik's books, the Eichmann trial and the Stalags. It recounts the history of the Stalags, their background and the controversy regarding this pulp fiction, considered by many a perverted literature, written by sexually sick individuals with twisted imaginations. The film's narrator (Libsker's voice-over) concludes: “The images in Ka-tzetnik's books and in the Stalags permeated Israeli consciousness and to this day this mixture of horror, sadism, and pornography serves to perpetuate the memory of the Holocaust" (2007). This stern statement is however undermined by the poignant question: "Did the Stalags in fact portray a reality silenced by the establishment?".

\footnotetext{
${ }^{4}$ In May 1977, the Right Wing in Israel (led by the Likud party), won a plurality in the elections, ending a 29-year political domination by the Left Wing (the Alignment/Labor party).

${ }^{5}$ Wolman's Hide and Seek (1980) follows the same narrative pattern. Balaban, a young homosexual, described by the children as someone "who doesn't even look like a man", is embraced by the young protagonist at the end of the film. The film draws a parallel between the way homosexuals were treated/abjected/excluded during the Holocaust and the way they were treated by the young underground fighters in pre-State Israel. Embracing the pariah is also part of Once I Was. Ya'akov, a Diasporic-looking Holocaust survivor is young Arik's mentor, to whom Arik refers at the end of the film as "my hero".

${ }^{6}$ Holocaust survivors comprised half of Israel's population during the second generation's comingofage.

${ }^{7}$ See, for example Marks (2002)—one of the ample examples of film theories centering on the phenomenology of cinema.
} 
In response to this question, the film: (1) moves between the defenders of Ka-tzetnik's literature (Yechiel Szeintuch among them), who claim that everything Ka-tzetnik wrote was based on his own experience, and his denouncers (e.g., Holocaust survivor and writer Ruth Bondy, historian Na'ama Shik and Hebrew literature scholar Dan Miron); (2) it employs parallel editing reenacting the temporal coincidence of the Eichmann trial and the Stalags; and (3) it establishes a clear relationship between the traumatic past of Eli Keidar, the original creator of the Stalag genre-the son of two camp survivors-and his fiction. The author thus argues that the film in fact subverts its overt politics by (unconsciously) suggesting that sexual violence affected "the second generation".

The cinematic rendition of the temporal coincidence of the Eichmann trial and the Stalags conveys a direct relationship between the two forms of contending with the fresh memory of the Holocaust. The parallel editing shows how, while survivors of the Holocaust, Ka-tzetnik among them, were being confronted daily on the witness stand with unbearable memories, their adolescent children were consuming sadomasochistic scenarios. When the film first cuts to the Eichmann trial, we see Eichmann's distorted frozen face behind the glass cell, followed by Attorney-General Hausner speaking, and people sitting on benches, listening to him. We then learn that the first Stalag was published directly after the commencement of the Eichmann trial. This juxtaposition conveys the idea that what could not be expressed verbally in any other shape or form (publicly or privately) had found a mouthpiece in the Stalags: namely that "sexualized violence" was an inherent part of the Nazi dehumanization plan in the Holocaust:

[V]iolent acts can be understood as sexualized if they are directed at the most intimate part of a person and, as such, against that person's physical, emotional, and spiritual integrity. [...] This definition of the term covers direct physical expression of violence that are bodily attacks, an unauthorized crossing of body boundaries. They range from flagrant sexual advances to rape. In Nazi concentration camps, sexualized violence also included forced sex labor, sex for survival, forced sterilization, forced abortion, and other medical procedures... and emotional expressions of violence, such as imposed public nakedness... infringement on intimate space, deplorable hygienic conditions, leering stares, suggestive insults, and humiliating methods of physical examination, all part of the constant impending danger of becoming the victim of sexual assault by the SS or camp guards. (Halbmayr, 2010, p. 30)

The role inversion in the Stalags-women as SS guards and sexual perpetrators, and allied POW as victims-tragically reflects how a victim of sexualized violence has in turn unconsciously victimized her son. The Stalags thus reflect a transgenerational phenomenon, resulting in a fantasy unleashed by the Eichmann trial.

To better understand this fantasy, we need to examine the film's treatment of this most salient element in the Stalags (women as SS guards and sexual perpetrators), as well as how the film relates it to the biography of the genre's creator. The first sequence of the film opens with a series of Stalag pictures. The first picture depicts the cover of the first Stalag, Stalag 13: the huge face of an SS officer (in the foreground), who bears a striking resemblance to Eichmann; on the right side of the picture (in the background) -is a much smaller image of a woman's torso, covered only by a brassiere. Her hands are chained to a wall and her naked body reveals traces of violence (blood). The content of the cover conveys sexual assault, and its composition, including the size difference of the two images, reflects the constant looming danger of becoming a victim of sexual assault by SS guards. The voice-over accompanying this shot reads from the Stalag: "There was nothing unusual in the way they lined up holding their heads up high" (2007).

What we have here is a prototype, underscored by the visual allusion to Eichmann: a male sadistic Nazi perpetrator and his female victims. The opening phrase, accompanying this image-“There was nothing 
unusual in the way they lined up"-contextualizes the shot, alluding thus to a situation that represents what had happened in reality. Clearly, the lining up of women in the camps had become by the early 1960s an image of what Alison Landsberg has termed "prosthetic memory" (Landsberg, 2004). This picture then fades out and others appear, all of which depict seductive, voluptuous blondes, wearing brown shirts with deep cleavage, tight pants, and shiny SS boots, their necks adorned with swastikas, while the voice-over announces "Nothing unusual except for the fact that these soldiers were women..." (Stalag, 2007). We are thereby transposed into the realm of fantasy. The novelty of the Stalags, we are told and shown, consisted in the sexual role-reversal. The voluptuous, sensual women of the Stalags, who are simultaneously a source of sexual stimulation and revulsion, thus suggest the effects of having lived with a mother whose memories of sexualized violence are still fresh in her body and mind, incapable of being worked through and inescapably transmitted to her children in the form of "radioactive transference" and "radioactive identification". These two concepts are used by Gampel (2005) in relation to the aftermath of social (although not necessarily sexual) violence:

For those who suffered the horrors of the camps at first hand, the events are still present, tangible, experienced in the body. The inherent image and the trauma left by these experiences are rooted in the body, in their sensory perception. These traumatic scenes, which the survivors pass on unconsciously, are inscribed in the imaginary world of their children in an acute and destabilizing manner. For the following generation, the trauma experienced by the parents on their flesh, becomes a fantasmatic traumatic reality. (p. 21)

The notion that radioactive traces of sexualized violence had infiltrated, body and soul, the children of Holocaust survivors is further substantiated by the treatment of the relationship between Eli Keidar's childhood experience and the Stalags. Keidar wrote Stalag 13 (1961), as well as all his other Stalags, under the pseudonym Mike Bader. Throughout the film, he relates his continual helplessness and terror of living with an unpredictable mother who had lost her entire family in the Holocaust, and blamed him for her suffering, constantly telling him that he was no good: "I've been living with that image since I was six years old. Even at a safe family moment I could be slapped. I was never secure. I realized my parents were unpredictable, and that I should be careful around them. Somehow even when they smiled I cringed".

Indeed, the most striking sequence in the film in regard to Keidar starts with a statement about his life in the shadow of trauma, establishing the idea of transgenerational trauma. After Keidar himself describes his apprehensions regarding his mother, the film cuts to a quote from Stalag 13, referring to the blind obedience to the female camp commander, because everyone knew that "the punishment for the slightest dissidence was death". During the voice-over of this fragment, the film does not show any images from the Stalags. It also refrains from using footage or stills from the camps. Instead, it shows a sequence of images depicting a dilapidated building - a visual metaphor for Keidar's ruined childhood, substantiated by Keidar, facing the camera: "A child absorbs this atmosphere and is affected by it". While we cannot detect any sexual overtones in Keidar's confession about his mother, Libsker's voice-over quoting the blind obedience to the female camp commander from Stalag 13, suggests that what Keidar's mother may have experienced, or just witnessed and feared, had been transferred to her son, who translated the abuse suffered at her hands into a fantasmatic form. This (cinematic) example is also (repeatedly) substantiated by publisher Uzi Narkis, Szeintuch, and others, who attest to the polymorphous experience of sexual perversity in the Nazi world. The film thus not only acknowledges that what precipitated the advent of the Stalags was the continuing experience of the effects of a psychic economy which had placed sexuality in the service of destruction, but also that it was precisely this reality that the Stalags' authors recognized in Ka-tzetnik's books. 


\section{Cinememory and Sexualized Violence}

Wooden Gun, which is set in the early 1950s, is the first coming-of-age Holocaust-related film that depicts Israel as a young State infiltrated by, as well as infatuated with, violence. The film is quite explicit about the connection between the violence suffered by Holocaust survivors in the camps and the violence practiced by their children, as a form of transgenerational acting-out. In a very subtle way, it also implies that sexual violence is part of this equation. The film evinces cinema as a visual form of postmemory whose efficacy in creating an ethical stand in relation to the transmission of violence is superior to all other art forms, including still photography, generating in fact a uniquely cinematic form of postmemory, which the author terms "cinememory".

In the last sequence of the film, Holocaust survivor Palestina takes Yoni, the film' young protagonist, into her shack, whose walls are covered with photographs of her dead family, including her two young children. Significantly, Yoni learns about Holocaust atrocities from a visual medium. He inspects the photographs carefully, and each time he looks at a new photograph, he asks who the people in it are. Palestina keeps quiet. This not only raises the question of the way she has survived, but also emphasizes the role of visual arts in representing the Holocaust and its aftermath. Yoni must figure out on his own what the photographs represent-the mass murder of Jews. When the camera zooms-in on an iconic photograph, we see a reaction-shot of Yoni's stupefied expression, and we hear guns firing on the soundtrack, conveying the way he vividly imagines the execution scene in the still photograph. The camera movement (the zoom-in) and the soundtrack emphasize cinematic expression (movement and sound). Furthermore, while the soundtrack reiterates phrases taken from Yoni's war games ("Kill him! Break his head! Don't be scared! ... ”), the iconic Holocaust still photograph comes to life, and is cinematically reenacted. Unlike the still photograph on the wall, documenting the liquidation of the Warsaw Ghetto, this scene manifests film's role in dealing both subjectively and ethically with the documentation available to us, in creating a unique form of postmemory: cinememory. The animation of the still photograph, which expresses Yoni's affect while viewing the photographs, aims to induce the same affect in the viewer. The soundtrack conflating the children's violence with that experienced by their parents in the Holocaust is too a connection that both Yoni and the spectators make.

What connects Palestina to the aspect of sexual violence inflicted on women is the film's allusion to Fellini's $81 \frac{1}{2}$ (1963), elaborating thus the notion of cinememory. In Fellini's protagonist's childhood memories the female character dominating his sexual fantasies (other than his mother) is Saraghina. Saraghina is a grotesque prostitute, dressed in rags barely covering her big body. Her hair is wild, she stomps barefoot in the sand-she lives in a dilapidated shack by the seashore-and her face is heavily made-up, her facial expressions (rendered in close-up) emitting ravenous sexuality and eroticism. Although Palestina's attire is not slovenly (rather, it suggests a past life), her hair is wild, she usually strolls the beach barefoot, like Saraghina, and she too lives in a dilapidated shack by the seashore. In several scenes, she is accompanied by a two-man survivor orchestra of saxophone and accordion. These scenes appear to be a tribute to Fellini's dream-like quasi-Surrealist style.

Unlike the young boys' jovial experience in $81 / 2$, however (they pay Saraghina to dance with them, to free them from the shackles of their Catholic puritan upbringing), Palestina's function in Wooden Gun is to balance Yoni's violent behavior. The children viciously attack her, calling her "lunatic". Her facial expressions and language are mad, not with lust (like Saraghina's), but with pain. The allusion to Saraghina, and the fact that 
the children violently attack Palestina (as a form of acting-out the violence experienced in the Holocaust by their parents), rather than see her erotically, are precisely what inscribes her as a victim of sexual violence/crimes. It thus becomes clear that women's sexuality was not attacked because they flaunted it (unlike Saraghina), but simply because they were women.

Holocaust-related films returned to the coming-of-age paradigm in the 2000s. In keeping with Wooden Gun, all films recreate the historical period of their protagonists' coming of age, but the creation of cinememory in relation to sexualized violence differs greatly from film to film. Burning Mooki stands out in its attempt to reenact the loss of humanity in the camps; hence its bluntness in dealing with sexualized violence. At an age when the young protagonist should be experiencing normal sexual latency, he is instead being constantly aroused by the perverse behavior of the adults (all Holocaust survivors) around him. In the first flash-back of the film, returning to 1967, the year of the victorious Six Day War, all Mooki remembers/recounts are: "what excited me the most were Aunt Jenia's tits" (Burning Mooki, 2008). The film covers three periods of the protagonist's life: early childhood, adolescence, and adulthood. The death of his mother triggers memories (rendered in flashbacks) showing how he has been seduced into committing incest with her when an adolescent. Constantly subjected to the lures of an incestuous mother (such as her asking him to paint her toenails and insisting on invading his privacy when he takes a bath), an angry and confused Mooki quits school and moves into a shack, where he reenacts the conditions of the camps (poor sanitation, mice, litter, lack of food and severe depression). After a failed attempt at sexual intercourse with his girlfriend, he storms out and runs home. He undresses and climbs into his mother's bed. What follows seems inevitable. The incest, however, leaves both of them in a state of emotional collapse. In Burning Mooki, the vulgar behavior of "uncle Yanek" (as well as of other male Holocaust survivors), scattered with sexual innuendoes, his attempt to rape the protagonist's young girlfriend, and his debaucheries-all modes of acting-out past experiences-suggest that sexual-related victimization was part of men's experience too.

As an adult, Mooki has severed all ties with his family, but it is clear that he is constantly tormented by his past, which continues to ruin his life-he drinks heavily, he appears neglected and slovenly, and is beyond consolation. "Burning Mooki" is a derogatory nickname that the schoolchildren has given him. It derives from a memorial song, "Our town is burning", sometimes performed by children on Holocaust Memorial Day. In the film, both the song and Mooki's nickname are a metaphor for how the second-generation children have become, in Dina Wardi's terminology, "memorial candles" (1992). Burning Mooki, like all the other Holocaust-related coming-of-age films, suggests that living in the shadow of a perverse sexual economy has affected the second generation in ways that are hard to imagine; and that mass violence begets traumas that penetrate the collective memory, which, as Gampel (2005) asserts, becomes permeated entirely with that same violence; traumas that may in turn become new origins of cruelty. Mooki's friend, who enlists in the army after his father (a Holocaust survivor) commits suicide, tells Mooki a story about an encounter with enemies in Lebanon, which suggests (like in Wooden Gun and Hide and Seek) an acting-out of violence on both the social and military levels.

The protagonist of Once I Was is Arik, the teenage son of a Holocaust survivor. His romantic and sexual involvement with his neighbor's cousin is intertwined with the sad story of two Holocaust survivors: his summer employer and mentor, Ya'akov, and the blond and beautiful Clara. Both live in downtown Haifa (a harbor city) - a liminal place, inhabited by social outcasts: Holocaust survivors with shady businesses, prostitutes, and smugglers. This large area, which reenacts some of the activities characteristic of the camps, symbolizes the collective unconscious. What takes place there during the time represented in the film (1968) 
represents the horrific past, which cannot be erased. Uptown Haifa, in contrast, represents those who want to be purged of such memories. Arik, the teenage protagonist of the film, lives with his parents on Mount Carmel. His father, also a Holocaust survivor, expresses his indignation at his son's attempts to learn whether what Ka-tzetnik has written is true.

Clara runs an illegal gambling club in her downtown apartment. She considers herself unfit to be a mother and so has sent her son to live on a kibbutz, and he only visits occasionally. She explicitly tells Arik that her son is better off there, because she is "incapable of raising a child". "Embarrassment, shame, fear, and especially a desire to hide the events from family members are motives for many victims of rape to remain silent" (Sinnreich, 2010, p. 108; Dror \& Linn, 2010), or to alienate the nearest and dearest. Ya'akov, a matchmaker and a smuggler, is clearly in love with Clara, but he does not dare approach her other than in his capacity of friend, lest it re-opens old wounds. The film is not explicit about Clara's past, but it does insist that we read certain signs (Ya'akov, who teaches Arik all about matchmaking, coaches him on how to "read the signs" of the unattached). When Meir, the chief librarian, needs to boost his self-confidence before Ya'akov introduces him to a possible future wife, Ya'akov takes Meir to Clara, who showers the latter with compliments on his manhood. At this point, the film distinguishes between how the viewer should read Clara's performance (as an act), as part of the subtext, and how Meir reads it (literally).

Clara's masquerade suggests a sexual experience that involves detaching herself from her sexuality and from any feelings associated with it. Clearly, this is how she managed, and still manages, to endure. When Clara tries to explain to Meir that she does not have feelings for him, she mentions that she had only acted in the way she did for Ya'akov's sake; whereupon Meir wrongly deduces that Clara is being forced into prostitution by Ya'akov. Determined to bring Ya'akov down, Meir tries to convince Arik to help him. Referring to Ka-tzetnik's House of Dolls, he says: "Listen to me carefully, a beautiful woman like her-how do you think she survived? Whoever survived must have done something". Here, cinememory takes on the form of a parapraxis, the English translation of Freud's Fehlleistung (1991 [1916]) and applied to the reading of cinematic texts by Elsaesser (2008):

I define parapraxis... as a kind of effort, a kind of persistence, usually one with unexpected or unintended results, including among others, reversals or displacements in time and space. For instance, one feature of parapraxis... is the way in which it often seems to figure the right thing at the wrong place, the wrong thing at the right time. (p. 109)

This parapraxis - the wrong reading (by Meir) of a present situation (Clara's apartment as a brothel), attesting to a right interpretation of her attractiveness, albeit relevant to another time and place-reinforces the effect (and affect) conveyed while viewing Clara managing her club: She always dresses up, her low-cut, tight evening gown revealing her shoulders and accentuating her bosom; and she is very secretive about her business. Driven by jealousy and frustration, Meir causes a big commotion, involving the police. The exposure of Ya'akov's illegal business makes huge headlines, and Clara, terrified, decides to sever her ties with the only friend she has, who really loves her-Ya'akov. Finally, unable to endure the burden of shame and the fear of revealing her past, she commits suicide.

In Intimate Grammar (adapted from a novel by David Grossman), the principal metaphor of the cinememory conveying the notion of sexualized trauma is a "diseased" tree-the more Aharon's father (a Holocaust survivor) tries to cure it, the faster its disease spreads. Up in the tree, the father, accompanied by Aharon (the film's protagonist), tells his son about the Holocaust. Both are enfolded by the diseased branches 
of the tree, the affected parts of which the father is painting with a white coating. The close-ups reveal an odd image of the tree's wounds-orifices, connoting human/woman's private parts. In her discussion of abject images of Jerusalem in Israeli films, Zanger (2012) notes that in Intimate Grammar "there is an incessant engagement with bodily secretions (including vomit, menstrual blood and ear wax), as well as sewage" (p. 187). Aharon's mother refers to her daughter's menstruation as repulsive, and she makes a connection between the diseased tree's spreading roots and the sewage flooding the family's apartment, establishing an image of woman's damaged sexuality flooding the apartment. Zanger (2012) rightly notes that the tree "connects the neighbors to their desires and fears" (p. 187). The author suggests that some of these fears are connected to sexual maturation in the shadow of women's trauma. Aharon, whose sexual maturation is imbued with the image of woman's sexuality as no different from that of sewage, an image underscored by the tree's sick branches, seeks to postpone his encounter with woman's sexuality by literally halting his growing-up. Unable to move past, or express, the trauma transmitted to him, he constantly practices the English present continuous tense.

Aharon's grandmother is insane, and so is the young attractive neighbor, a Holocaust survivor, who expresses her attraction to Aharon's father by forcing him to knock down all the walls in her apartment. This act of demolition-another metaphor of cinememory-expresses the neighbor's inward aggression; the destruction of women's bodily boundaries and the infringement of intimate space; as well as the way in which trauma blurs the boundaries of private/public spheres-the way it infiltrates the collective memory/experience. The fact that Aharon's mother is there, supervising the work (sitting with Aharon on a sofa, as if watching a film), ensuring that the project does not develop into a sexual affair, is precisely what renders the neighbor's advances, as well as the act of devastation, sexual.

\section{Conclusions}

In conclusion, the coming-of-age Holocaust-related films in Israel are cinememory works. By associating sexual violence as experienced in the Holocaust, mostly by women, with the violence practiced by Israeli society, these films explore the lasting implications of growing-up in the shadow of sexualized trauma, the connections between past and present. Through cinematic expression, they create an ethics of remembrance-cinememory - in regard to sexualized violence, which might help Israeli society to grapple both with the unrelenting memories of sexualized violence and with the various forms in which violence at large has been (and continues to be) acted-out.

\section{References}

Abramovich, D. (2007). The Holocaust world of Yechiel Fajner. Nebula, 4(3), 20-39.

Allen, A. T. (1997). The Holocaust and the modernization of gender: A historiographical essay. Central European History, 30(3), 349-364.

Amesberger, H. (2010). Reproduction under the swastika: The other side of the glorification of motherhood. In S. M. Hedgepeth, \& R. G. Saidel (Eds.), Sexual violence against Jewish women during the Holocaust (pp. 139-155). Waltham, MA: Brandeis University Press.

Amir, A. (Producer), \& Bergman, N. (Director). (2010). Intimate grammar [Motion picture]. Israel: Libretto Films; Norma Productions. Avisar, I. (2011). The Holocaust in Israeli cinema as a conflict between survival and morality. In M. Talmon, \& Y. Peleg (Eds.), Israeli cinema: Identities in motion (pp. 151-167). Austin, TX: University of Texas Press.

Azrieli, S. (Producer), \& Trope, T. (Director). (1987). Tel Aviv-Berlin [Motion picture]. Israel: Admor International Productions. Bader, M. (1961). Stalag 13. Tel Aviv: Yanshuf. 
Baer, E., \& Goldenberg, M. (Eds.) (2003). Experience and expression: Women, the Nazis, and the Holocaust. Detroit, MI: Wayne State University Press.

Baumel, J. T. (1998). Double jeopardy: Gender and the Holocaust. London: Valentine Mitchell.

Baumel, J. T. (2000). "You said the words you wanted me to hear but I heard the words you couldn't bring yourself to say": Women's first person accounts of the Holocaust. The Oral History Review, 27(1), 17-56.

Ben-Sefer, E. (2010). Forced sterilization and abortion as sexual abuse. In S. M. Hedgepeth, \& R. G. Saidel (Eds.), Sexual violence against Jewish women during the Holocaust (pp. 156-174). Waltham MA: Brandeis University Press.

Bergen, D. (2013). What do studies of women, gender, and sexuality contribute to understanding the Holocaust?. In M. Goldenberg, \& A. H. Shapiro (Eds.), Different horrors, same hell: Gender and the Holocaust (pp. 16-37). Seattle WA: University of Washington Press.

Chatwood, C. (2010). Schillinger and the dancer: Representing agency and sexual violence in Holocaust testimonies. In S. M. Hedgepeth, \& R. G. Saidel (Eds.), Sexual violence against Jewish women during the Holocaust (pp. 61-74). Waltham, MA: Brandeis University Press.

Cherrick, B. (Producer), \& Lejtes, J. (Director). (1947). The great promise [Motion picture]. Palestine/USA: Jewish National Fund.

Danon, M., \& Riklis, E. (Producer), \& Chaplin, L., \& Chaplin S. (Director). (2008). Burning Mooki [Motion picture]. Israel: Inosan Productions.

Doerr, K. (2000). Memories of history: Women and the Holocaust in autobiographical and fictional memoirs. Shofar: An Interdisciplinary Journal of Jewish Studies, 18(3), 49-63.

Dror, E. \& Linn, R. (2010). The shame is always there. In S. M. Hedgepeth, \& R. G. Saidel (Eds.), Sexual violence against Jewish women during the Holocaust (pp. 275-291). Waltham, MA: Brandeis University Press.

Edery, M. (Producer), \& Nesher, A. (Director). (2010). Once I was [Motion picture]. Israel: Metro Communications; Artomas Communications; United Channel Movies.

Elsaesser, T. (2008). Absence as presence, presence as parapraxis. Framework: The Journal of Cinema and Media, 49(1), 106-120.

Flaschka, M. J. (2010). "Only pretty women were raped”: The effect of sexual violence on gender identities in the concentration camps. In S. M. Hedgepeth, \& R. G. Saidel (Eds.), Sexual violence against Jewish women during the Holocaust (pp. 77-93). Waltham MA: Brandeis University Press.

Freud, S. (1991 [1916]). Parapraxes. In J. Strachey, \& A. Richards (Eds.), Sigmund Freud: Introductory lectures on psychoanalysis (pp. 39-108). London: Penguin Books.

Gampel, Y. (2005). Ces parents qui vivent à traversmoi: Les enfants des guerres (These parents who live through me: Children of wars). Paris: Librairie Arthème Fayard.

Gertz, N. (2004). Holocaust survivors, aliens and others in Israeli cinema and literature. Tel Aviv: Am Oved.

Goldenberg, M. (1996). From a world beyond: Women and the Holocaust (Review essay). Feminist Studies, 22, 667-687.

Goldenberg, M. (2013). Sex-based violence and the politics and ethics of survival. In M. Goldenberg, \& A. H. Shapiro (Eds.), Different horrors, same hell: Gender and the Holocaust (pp. 99-131). Seattle WA: University of Washington Press.

Halbmayr, B. (2010). Sexualised violence against women during Nazi "racial" persecution. In S. M. Hedgepeth, \& R. G. Saidel (Eds.), Sexual violence against Jewish women during the Holocaust (pp. 29-44). Waltham, MA: Brandeis University Press.

Hardy, J., Sanders, R., \& Evan, E. (Producer), \& Moshenson, I. (Director). (1978). Wooden gun [Motion picture]. Israel: Hardysanders Motion Pictures; Makor Films.

Heinemann, M. E. (1986). Gender and destiny: Women writers and the Holocaust. Westport, CT: Greenwood.

Hirsch, M. (2008). The generation of postmemory. Poetics Today, 29(1), 105-118.

Horowitz, S. S. (2000). Gender, genocide and Jewish memory. Prooftexts: A Journal of Jewish Literary History, 20(1), 158-190.

Jacobs, J. (2010). Memorializing the Holocaust: Gender, genocide and collective memory. London and New York: I. B. Tauris.

Justin, J., \& Wolman, D. (Producer), \& Wolman, D. (Director). (1980). Hide and seek [Motion picture]. Israel: Israel Film Fund.

Ka-tzetnik 135633. (1955). House of dolls. (M. M. Kohn, Trans.). New York, NY: Simon \& Schuster.

Ka-tzetnik 135633. (1963). Atrocity. (M. M. Kohn, Trans.). New York, NY: Lyle Stuart.

Ka-tzetnik 135633. (1977). Sunrise over hell. (Y. L. Barukh, Trans.). London: W. H. Allen.

Kaplanski, D. (Producer), \& Berman, V. (Director). (2007). Josef and Maria [Motion picture]. Israel: Six Productions.

Kremer, L. S. (1999). Women's Holocaust writing: memory and imagination. Lincoln NE: University of Nebraska Press. 
Landsberg, A. (2004). Prosthetic memory: The transformation of American remembrance in the age of mass culture. New York, NY: Columbia University Press.

Lejtes, J. (Producer \& Director). (1952). The faithful city [Motion picture]. Israel/USA: Moledet Films.

Levenkron, N. (2010). "Prostitution", rape, and sexual slavery during World War II. In S. M. Hedgepeth, \& R. G. Saidel (Eds.), Sexual violence against Jewish women during the Holocaust (pp. 13-28). Waltham, MA: Brandeis University Press.

Levin, M., \& Klein, H. (Producer), \& Klein, H. (Director). (1947). My father's house [Motion picture]. Palestine/USA: Jewish National Fund.

Linden, R. R. (1993). Making stories, making selves: Feminist reflections on the Holocaust. Columbus, OH: Ohio State University Press.

Marks, L. U. (2002). Touch: Sensuous theory and multisensory media. Minneapolis: University of Minnesota Press.

Mushaben, J. M. (2004). Memory and the Holocaust: Processing the past through a gendered lens. History of the Human Sciences, $17(2 / 3), 147-185$.

Myers, F. M. (2007). Absent fathers, present mothers: Images of parenthood in Holocaust survivor narratives. Nashim: A Journal of Jewish Women's Studies, 13, 155-182.

Nussbam, R. (Producer \& Director). (1960). The sun rises on the horizon [Motion picture]. Israel/Germany: Aero Film; Ran Film.

Ofer, D., \& Weitzman, L. (Eds.) (1998). Women and the Holocaust. New Haven, CT: Yale University Press.

Patterson, D. (2013). The Nazi assault on the Jewish soul through the murder of the Jewish mother. In M. Goldenberg, \& A. H. Shapiro (Eds.), Different horrors, same hell: Gender and the Holocaust (pp. 163-176). Seattle WA: University of Washington Press.

Pinchevski, A., \& Brand, R. (2007). Holocaust perversions: The Stalags pulp fiction and the Eichmann Trial. Critical Studies in Media Communication, 24(5), 387-407.

Pine, L. (2008). Gender and Holocaust victims: A reappraisal. Journal of Jewish Identities, 1(2), 121-141.

Podolsky, A. (2010). The tragic fate of Ukrainian women under Nazi occupation, 1941-1944. In S. M. Hedgepeth, \& R. G. Saidel (Eds.), Sexual violence against Jewish women during the Holocaust (pp. 94-107). Waltham MA: Brandeis University Press.

Ringelheim, J. M. (1984). The unethical and the unspeakable: Women and the Holocaust. Simon Wiesenthal Center Annual, 1, 69-87.

Ringelheim, J. M. (1985). Women and the Holocaust: A reconsideration of research. Signs, 10(4), 741-761.

Rittner, C., \& Roth, J. K. (Eds.) (1993). Different voices: Women and the Holocaust. New York, NY: Paragon House.

Rizzoli, A. (Producer), \& Fellini, F. (Director). (1963). 8²/2 [Motion picture]. Italy/France: Cineriz; Francinex.

Saidel, R. G. (2006). The Jewish women of Ravensbrück. Madison, WI: University of Wisconsin Press.

Schoenfeld, G. (2001). Feminist approaches to the Holocaust. Prooftexts: A Journal of Jewish Literary History, 21(2), $277-283$.

Sharir, C. (Producer), \& Ben-Dor, O. (Director). (1994). Newland [Motion picture]. Israel: Sharir Films.

Sinnreich, H. J. (2010). The rape of Jewish women during the Holocaust. In S. M. Hedgepeth, \& R. G. Saidel (Eds.), Sexual violence against Jewish women during the Holocaust (pp. 108-123). Waltham MA: Brandeis University Press.

Sivan, M. (2010). "Stoning the messenger": Yehiel Dinur's House of Dolls and Piepel. In S. M. Hedgepeth, \& R. G. Saidel (Eds.), Sexual violence against Jewish women during the Holocaust (pp. 200-216).Waltham MA: Brandeis University Press.

Slonim, N. (Producer), \& Gross, N. (Director). (1963). The cellar [Motion picture]. Israel: Shai Films.

Smith, R. W. (1994). Women and genocide: Notes on an unwritten history. Holocaust and Genocide Studies, 8(3), 315-334.

Sommer, R. (2010). Sexual exploitation of women in Nazi concentration camp brothels. In S. M. Hedgepeth, \& R. G. Saidel (Eds.), Sexual violence against Jewish women during the Holocaust (pp. 45-60). Waltham MA: Brandeis University Press.

Szeintuch, Y. (1999). Key concepts in the writings of Ka-tzetnik. Hulyot: Studies in Yiddish Literature and its Relationship with Hebrew Literature, Vol. 5 (pp. 275-290). Jerusalem: Haifa, Tel Aviv and Bar Ilan Universities \& Beit Lochamei Hagetaot.

Szeintuch, Y. (2003). KATZETNIK 135633: A series of dialogues with Yehiel De-Nur. Jerusalem: Beit Lochamei Hagetaot and Dov Sadan Institute.

Szeintuch, Y. (2009). Salamandra: Myth and history in Ka-tzetnik’s writings. Jerusalem: DovSadan Institute.

Tec, N. (2003). Resilience and courage: Women, men and the Holocaust. New Haven, CT and London: Yale University Press.

Wardi, D. (1992). Memorial candles: Children of the Holocaust. (N. Goldblum, Trans.). New York, NY: Routledge.

Waxman, Z. (2003). Unheard testimony, untold stories: The representation of women's Holocaust experiences. Women's History Review, 12(4), 661-677.

Waxman, Z. (2010). Rape and sexual abuse in hiding. In S. M. Hedgepeth, \& R. G. Saidel (Eds), Sexual violence against Jewish women during the Holocaust (pp. 124-136). Waltham MA: Brandeis University Press. 
Yosef, R. (2004). Beyond flesh: Queer masculinities and nationalism in Israeli cinema. New Brunswick, New Jersey, and London: Rutgers University Press.

Zanger, A. (2012). Place, memory and myth in contemporary Israeli cinema. Portland, OR: Vallentine Mitchell.

Zimmerman, M. (2002). Leave my Holocaust alone: The impact of the Holocaust on Israeli cinema and society. Haifa: Haifa University Press and Zmora-Bitan. 